PAWEŁ SCHMIDT

Uniwersytet Łódzki

Wydział Filozoficzno-Historyczny

Instytut Etnologii i Antropologii Kulturowej

\title{
Kultura zWANA LUdoWA . MARTWE POJĘCIE CZY PERSPEKTYWA BADANIA LOKALNOŚCI?
}

O roku w marcu przed starą ochotnicką kuźnią zbiera się kilku miejscowych gazdów by wspólnie z synem nieżyjącego już kowala Jwyklepać lemiesze swoich drewnianych pługów, podostrzyć i uzupełnić stalowe zęby drewnianych bron, po prostu wyszykować narzędzia do pierwszej w tym roku orki. Niedługo bowiem wyjdą z końmi na niewielkie poletka już nawiezione obornikiem, by przygotować gorczańską, nieurodzajną ziemię do wydania plonów w postaci owsa potrzebnego do wykarmienia konia, który w przyszłym roku znów pociągnie pług rozdzierający górskie zbocze bruzdami zagonów w tym samym celu. Ten obraz nie jest opisem wydobytym z dziewiętnastowiecznej literatury czy relacji ludoznawców, nie został również wywołany z zasobów pamięci jednego z ochotnickich nestorów. Przedstawiona sytuacja, w której po raz pierwszy dane mi było uczestniczyć w 2004 roku była obiektem mojego badawczego zdziwienia zmuszającego do refleksji, wywołującego ciekawość poznania i chęć zrozumienia lokalnego, ochotnickiego świata, który mimo zmian wywołanych standaryzacją nowoczesnych zachowań i stylów bycia zachował treści niemal rodem z innej epoki - z romantycznych w swym charakterze opisów wsi dokonywanych przez dawnych literatów, podróżników czy znacznej części etnografów. Obraz gazdów szykujących narzędzia do pierwszej orki wywołał iluzję doświadczania świata tradycyjnych wartości, norm i nakazów zmuszających tych ludzi do podjęcia jedynego znanego im działania mającego zapewnić dostatek w jedynej znanej im formie. Jednak ich wiedza w XXI wieku wykracza znacznie poza ramy tradycyjnej lokalnej kultury. 
Zamiast uprawiać hektar ziemi, zdawać by się mogło tylko po to by wykarmić konia potrzebnego do utrzymania tegoż hektara, mogliby przecież odwołać się do znanych choćby z Ochotnicy działań i założyć gospodarstwo agroturystyczne lub pensjonat, firmę transportową, sklep albo podjąć pracę poza rodzinną wsią. Jednak mimo wiedzy o alternatywnych wzorach działania sięgają oni do tradycyjnych treści kultury by usankcjonować swoje istnienie w lokalnej rzeczywistości, by być kimś, by móc powiedzieć: Jestem gazdą. Tylko po co być gazdą w XXI wieku?

Właściwie należałoby sformułować pytanie inaczej: Dlaczego współcześnie tak istotne jest dla tych ludzi konstytuowanie sensu odnoszonego nie do ponowoczesnej rzeczywistości ale do lokalnego świata? Ba, świata tradycyjnych znaczeń, wśród których ziemia czy koń wyznaczały status społeczny ich posiadacza. Znaczenia te, układające się $\mathrm{w}$ zespoły treści zrozumiałe i funkcjonujące w konkretnej zbiorowości ludzkiej określały konstrukt zwany przez badaczy kulturą ludową. Jednak już Jan Stanisław Bystroń mówił o tej kulturze w czasie przeszłym, lokując ją jako zjawisko, które przeminęło bezpowrotnie nawet w czasach gdy pisał swe dzieło ${ }^{1}$. Kilkanaście lat temu Roch Sulima ujął to bardziej dosadnie, stwierdzając, że „kultura ludowa umarła. Żyje jej mit...”2.

\section{Mityzacja kultury ludowej}

W trakcie jednego z wakacyjnych wyjazdów trafiłem do skansenu. Chałupa, zagroda, wiatrak... We wnętrzu chałupy idealny porządek - nie tyle wszechobecna czystość, która mogłaby świadczyć o zaradności gospodyni, ile odzwierciedlenie podręcznikowego układu przestrzeni, odwzorowanie kosmogonii tradycyjnego domu. Piec i święty kąt wyznaczające centrum, obrazy strzegące granic, ława, dwa łóżka z nagromadzoną „pod sufit" pościelą i... zaprzeczające temu porządkowi resztki posiłku na ceramicznych talerzach oraz otwarta nie wiedzieć czemu skrzynia odkrywająca schowane w niej skarby - elementy kaszubskiego stroju. Od tej scenografii oddzielała zwiedzającego turystę bariera w postaci czerwonej liny rozpiętej na dwóch metalowych słupkach.

${ }^{1}$ Zob. J. S. Bystroń, Kultura ludowa, Wydawnictwo Trzaska, Evert i Michalski, Warszawa 1947.

2 R. Sulima, Kultura ludowa i polskie kompleksy, [w:] Czy zmierzch kultury ludowej?, pod red. S. Zagórskiego, Wydawnictwo Stopka, Łomża 1997, s. 115. 
Ta czerwona lina skojarzyła mi się z granicą pomiędzy światem współczesnym umożliwiającym mi w czasie wolnym od codziennej pracy dotarcie do dowolnego dostępnego mi miejsca na ziemi a światem nieistniejącej już tradycyjnej kultury wsi zamkniętej kiedyś w dostępnej jej uczestnikom przestrzeni zwanej przez badaczy orbis interior, a obecnie ograniczonej do rekonstrukcji kaszubskiej izby. Z granicą pomiędzy światem ciągłego ruchu, chaosu pojęć i wartości, płynnych znaczeń i światem czytelnego porządku, w którym każdy obiekt ma swoje miejsce i ugruntowane znaczenie. Światem, którego ram nie sposób przekroczyć, światem, który bezpowrotnie przeminął i został zatrzymany wolą muzealników w kontrowersyjnej dla etnografa aranżacji wnętrza wiejskiego domu.

Znalezienie się na granicy pomiędzy ładem przeszłości i nieporządkiem płynnej nowoczesności wywołało poczucie tęsknoty za sielską rzeczywistością wsi rozumianej jako odzwierciedlenie i efekt boskiego porządku, zrozumiałego teleologicznego ładu pozbawionego konieczności rozpatrywania relatywnych sensów otaczającego mnie świata. Czy taką samą tęsknotę odczuli inni zwiedzający? Nie wiem. Możliwe jednak, że takim samym odczuciom poddani byli opisujący wieś polską przedstawiciele romantyzmu, Młodej Polski, a także wsi tej badacze - od dziewiętnastowiecznych ludoznawców przez pozytywistycznych etnografów po współczesnych antropologów i socjologów. Nie sposób bowiem oprzeć się wrażeniu, że wszyscy oni odnosili się (i często nada odnoszą) do obrazu rolniczego, poukładanego świata, w którym tradycyjne wartości i mechanizmy dyktowały rytm ludzkiego życia i determinowały sensy nakładane przez mieszkańców wsi na doświadczane obiekty otoczenia. W świecie tym każde działanie zgodne z tradycją było racjonalne - każde działanie nieracjonalne stawało się obce, a więc wyrzucane poza ramy własnej kultury.

$\mathrm{Na}$ aspekt tęsknoty za uporządkowaniem rzeczywistości w nowoczesnym, nieuporządkowanym świecie zwraca uwagę Maria Wieruszewska:

Na tle obserwowanego konfliktu standardów racjonalności, zresztą kluczowego dla współczesnego świata, łatwiej zrozumieć ruchy prowadzące do odradzania się więzi plemiennych, etnicznych i religijnych. Tym samym otwiera się pole dla postawy regresywnej. Sprzyja jej z jednej strony chęć porzucenia realiów chaosu, dotykającego również świat nauki, a z drugiej strony potrzeba swego rodzaju wędrówki regresywnej w poszukiwaniu wiedzy archetypowej. Tym wyjaśnić się da niezbędność mitologizowania jako próby przezwyciężenia chaosu doświadczenia. Mitologi- 
zacja pomaga w uzyskaniu wzorca porządkującego doświadczenie, zarówno badaczy, jak i badanych ${ }^{3}$.

Kultura ludowa, zawarte w niej wartości i znaczenia, stały się odskocznią od chaosu nowoczesności. Jakże chętnie sięgamy po „chleb na tradycyjnym zakwasie”, „szynkę wiejską” czy „kiełbasę gospodarza”. Znaczenia wydobyte ze świata niepodlegającego już współczesnemu doświadczeniu przeniknęły do świata nowoczesności i zostały nałożone na wyselekcjonowane z ogółu rzeczywistości obiekty mające pełnić rolę artefaktów tradycyjnego porządku przeciwstawianego chaosowi płynnej nowoczesności.

Mechanizm mityzacji można określić jako nadawanie sensowi formy, jako zamienianiu wartości w fakty ${ }^{4}$. W aspekcie kultury ludowej oznaczałoby to, że abstrakt jakim jest ta kultura, stanowiący dla mieszkańców tradycyjnej wsi ramy ograniczające dostępny im zasób znaczeń, do których odnosili oni swe działania, stał się dla badaczy oraz uczestników nowoczesnej rzeczywistości społeczno-kulturowej namacalnym bytem, którego przejawy można doświadczać we współczesnej kulturze wsi.

I nie tylko wsi... Treści tradycyjnej kultury wiejskiej zostały upowszechnione wykraczając poza konteksty lokalne. To, co stanowiło kiedyś o odrębności lokalnej społeczności, jak choćby elementy i wzornictwo stroju, „ludowe mądrości” zawarte w przysłowiach czy w wiedzy leczniczej dawnych pokoleń, wreszcie tradycyjna, lokalna architektura, weszły do społecznie podzielanych zasobów wiedzy i stały się treściami wykorzystywanymi powszechnie w wielu działaniach ludzi, niezależnie od specyfiki regionu czy pochodzenia autora tych działań. Moda na „ludowość” pojawiała się oczywiście w różnych okresach historii Polski, jednak w czasach nowoczesnych zmityzowana kultura ludowa jako konstrukt społecznie podzielanej wiedzy jest potencjalnie dostępna i znana każdemu mieszkańcowi Polski. Stało się tak nie tylko dzięki kulturowej modzie na wiejskie karczmy, kwieciste chusty czy muzykę folkową i wykorzystywanie ludowych motywów w popkulturze. Popularyzacji kultury ludowej towarzyszyła i towarzyszy nadal działalność instytucjonalna muzeów, ośrodków kultury wreszcie

${ }^{3}$ M. Wieruszewska, Antropologizacja badań wsi. Zaniechania, potrzeby, możliwości, [w:] Nowe inspiracje socjologii wsi, pod red. H. Podedwornej, Wydawnictwo Naukowe SCHOLAR, Warszawa 2011, s. 30.

${ }^{4}$ C. Robotycki, S. Węglarz, Chłop potęga jest i basta. O mityzacji kultury ludowej $w$ nauce, „Polska Sztuka Ludowa” 1983, nr 1-2, s. 3-8. 
szkoły. W każdym polskim mieście działają zespoły pieśni i tańca mające $\mathrm{w}$ repertuarze inscenizowane rekonstrukcje folklorystyczne z każdego niemal zakątka kraju. W niemal każdej szkole dzieci uczą się śpiewać krakowiaków, trojaków czy polek wyrwanych z kontekstu kultury tradycyjnej wsi tak samo, jak osadzane przez ich rodziców w miejskim, ponowoczesnym świecie rekonstrukcje tradycyjnych oczepin sprowadzonych do roli atrakcji weselnej biesiady.

Swoboda z jaką treści kultury tradycyjnej przenikają do kultury popularnej czy masowej może świadczyć o głębokim zakorzenieniu jej treści w społecznie podzielanych zasobach wiedzy. Łatwość utożsamiania kultury ludowej z kulturą narodową, a raczej wywodzenie tej drugiej ze świata tradycyjnej wsi, można wywodzić już z działań ideologicznych polskiego regionalizmu przełomu XIX i XX wieku, kiedy ruch regionalny bardziej angażował się w akcje budzenia polskiej świadomości narodowej ponad lokalnymi podziałami niż w podkreślanie regionalnych odmienności i odrębności. Treści kultury ludowej, głównie treści wiejskiego folkloru stawały się tym samym dobrem narodowym dostępnym każdemu Polakowi i służyły narodowej identyfikacji w równym chyba stopniu, jak wyidealizowane obrazy mocarstwowej Polski kreowane „ku pokrzepieniu serc”.

Jest to przykład rozumienia kultury odnoszący się do przedmiotowego ujmowania tradycji, tak charakterystyczny dla systemów ideologicznych odwołujących się do wspólnotowego wyobrażenia wartości, takich jak Bóg, Naród, Ojczyzna. Należy jednak pamiętać, że we współczesnym świecie jak zauważył Zygmunt Bauman - zapomina się, iż tradycja „nigdy nie jest »dana« z góry, że istnieje tyko w procesie ustawicznej rekapitulacji, przez to, że się ją konstruuje jako »wspólne dziedzictwo «, (...) że zamierzchłość jej korzeni jest tylko projekcją emocjonalnego nasycenia dzisiejszej mgławicowej wspólnoty..." ${ }^{5}$. Dlatego tradycja i to, co uznane za tradycyjne nie może być konstruowane współcześnie, może być co najwyżej odtwarzane z możliwie dokładną dbałością o szczegóły. Obrazując nowe rozumienie tradycji można stwierdzić, że wspólne kolędowanie przy wigilijnym stole w świecie ponowoczesnym nie jest czynnością tradycyjną samą w sobie. Wspólny śpiew nie przeciwstawia się nowoczesności. Tradycyjne są w ponowoczesnym rozumieniu same kolędy - ich treść odnosi się bowiem do „szczęśliwej

${ }^{5}$ Z. Bauman, Wieloznaczność nowoczesna - nowoczesność wieloznaczna, Wydawnictwo Naukowe PWN, Warszawa 1995, s. 286. 
przeszłości”, z której pochodzą, oraz do przed- i anty-nowoczesnego, danego od Boga teleologicznego ładu, o którym traktują.

Czy w pozalokalnie i przedmiotowo rozumianej tradycji, a co za tym idzie kultury, mieści się „bycie gazdą” i szykowanie starych narzędzi do corocznej orki? W wymiarze lokalnym tradycyjna kultura wydaje się być czymś innym - niezwiązanym z narodowymi identyfikacjami czy folklorystycznymi teatralizacjami.

\section{Kultura ludowa a świat życia codziennego}

Zakładam, że dla mieszkańca tradycyjnej wsi XIX czy pierwszej połowy $\mathrm{XX}$ wieku, kultura ludowa stanowiła zespół treści konstytuujących jego świat życia codziennego. Stanowiła także ramę znaczeń ograniczających ten świat do jedynych dostępnych lub jedynych pragmatycznych sensów podejmowanych przez niego działań. U podstaw takiego ujęcia kultury leży umieszczenie niniejszych rozważań w sposobie interpretacji wyrosłym z fenomenologii społecznej Alfreda Schütza i społecznego konstrukcjonizmu Petera L. Bergera i Thomasa Luckmanna. Zgodnie z nim zakładam, że znaczenia służące każdemu człowiekowi do opisu otaczającej go rzeczywistości są mu zawsze potencjalnie dostępne, są niejako „pod ręką”. Opis ten, a co za tym idzie rozumienie świata, dokonywany jest bowiem w odniesieniu do zasobów wiedzy potocznej, do których

przynależy wiedza o tym, że świat, w którym żyjemy, jest światem mniej lub bardziej określonych obiektów, posiadających mniej lub bardziej określone cechy, obiektów pomiędzy którymi poruszamy się, które stawiają nam opór i na które możemy oddziaływać. Żaden z tych obiektów nie jest spostrzegany jako wyizolowany. Jest on od razu obiektem w perspektywie tego, co już znane i swojskie, który ustanawia wiedza podręczna, traktowana, aż do odwołania, jako nie podlegająca dyskusji, to znaczy taka, w którą się nie wątpi, chociaż w każdym momencie można w nią zwątpić ${ }^{6}$.

To „naturalne” podejście do rzeczywistości, determinujące działania podejmowane w życiu codziennym, wolne jest od refleksji nad niuansami tej rzeczywistości, nad sposobem konstytuowania znaczeń i dystrybucji zasobów wiedzy. Wszelkie obiekty i przypisane im znaczenia są bowiem dostępne jako typowe, odnoszące się do uprzednich doświadczeń tych samych, takich

${ }^{6}$ A. Schütz, Potoczna i naukowa interpretacja ludzkiego działania, [w:] Kryzys i schizma. Antyscjentystyczne tendencje w socjologii współczesnej, t. 1, pod red. E. Mokrzyckiego, Wydawnictwo Naukowe PWN, Warszawa 1984, s. 142-143. 
samych lub podobnych obiektów znajdujących się w zasięgu potencjalnego poznania. U podstaw rozumienia rzeczywistości i wiedzy o niej znajduje się jednak założenie, że świat doświadczany przeze mnie jest potencjalnie dostępny i doświadczany przez innego. Jest światem społecznym podzielanym przez mniej lub bardziej znanych i mniej lub bardziej znaczących ludzi, dla których stanowi on pole działania, miejsce egzystencji i realizacji własnych, indywidualnych tożsamości. Ten „świat życia codziennego”

powinien być rozumiany jako świat intersubiektywny, który istniał długo przed naszymi narodzinami i był doświadczany oraz interpretowany przez innych naszych przodków - jako świat zorganizowany. Obecnie dany jest naszemu doświadczeniu i interpretacji. Podstawą wszelkiej interpretacji świata jest zasób poprzednich doświadczeń, zarówno naszych własnych, jak i przekazanych nam przez rodziców i nauczycieli, które w postaci „wiedzy podręcznej” służą jako schemat odniesienia7.

Nie oznacza to jednak, że świat ten jest jednorodny i jednakowy w każdej rzeczywistości społeczno-kulturowej. Intersubiektywność świata życia codziennego oznacza ciągłe interpretacje i reinterpretacje „świata znajdującego się w moim zasięgu"8 wyselekcjonowanego z ogólnego kontekstu rzeczywistości intencją autorów tych interpretacji. W świecie tradycyjnej wsi ramami takich interpretacji była kultura konkretnej społeczności konstytuującej konkretny, swój świat lokalny. Pozostaje to w zgodzie ze zdaniem J. S. Bystronia, dla którego kulturę ludową jak i kulturę w ogóle należy ujmować jako „zespół treści kulturalnych ukształtowany w danej grupie społecznej w określonym, czasie"9. Treści te zostały przecież ukonstytuowane w stałych interakcjach, w jakie wchodzili ze sobą i swoim światem mieszkańcy tradycyjnej wsi. Treści i zawarte w nich znaczenia odnosiły się do przeszłości - świata przodków, kształtowały wyobrażenia przyszłości - nawet jeśli wskutek negatywnej oceny zmian i dążności do jednorodności treści kulturowych w obrębie konkretnego świata lokalnego przyszłość miała być odzwierciedleniem przeszłości. Były jednak dokonywaną „tu i teraz” konstrukcją świata - nawet jeśli polegała ona na pozornym rekonstruowaniu świata przodków poprzez segregowanie treści ujmowa-

7 A. Schütz, O wielości światów. Szkice z socjologii fenomenologicznej, tłum. B. Jabłońska, Zakład Wydawniczy »NOMOS«, Kraków 2008, s. 18.

${ }^{8}$ Tamże, s. 30-34.

9 J. S. Bystroń, dz. cyt., s. 18. 
nych w czytelnych dla jego uczestników dychotomiach dobra i zła, swojskości i obcości.

Tradycyjny świat lokalny konstruowany był działaniami jego uczestników odnoszącymi się do społecznie podzielanej wiedzy o tym świecie. Jeśli praca na roli była społecznie uznawana za racjonalny sposób zabezpieczenia swoich podstawowych potrzeb, była nie tylko dobra czy przydatna, ale wyznaczała także status społeczny gospodarza, służyła wypracowaniu sensów nakładanych na posiadanie ziemi i samą ziemi wartość, stawała się osią, wokół której konstytuowano pojmowanie czasu (np. kalendarz rolny czy cykliczny podział doby). Intersubiektywnie podzielany sens takiej pracy uprawomocniał opisane we wstępie działania - odnosił je bowiem nie do samej czynności szykowania się do pierwszej orki ale do społecznego zasobu wiedzy o lokalnym świecie będącym dla jego uczestników światem życia codziennego. Należy jednak zaznaczyć, że jakkolwiek zasób ten

\begin{abstract}
przedstawia codzienny świat w sposób zintegrowany, zróżnicowany ze względu na strefy bliskości i oddalenia ${ }^{10}$, całość tego świata pozostaje nieprzenikniona. (...) Nie mogę wiedzieć wszystkiego co można, o tej rzeczywistości. Nawet jeżeli - przykładowo - jestem despotą w mojej rodzinie i wiem o tym, nie mogę znać wszystkich czynników, które składają się na stałe powodzenie mojego despotyzmu. Wiem, że moje polecenia są zawsze respektowane, ale nie mogę być pewny wszystkich kroków i wszystkich motywów, jakie znajdują się między wydaniem i wykonaniem moich poleceń. Zawsze są jakieś rzeczy, które dzieją się „poza moimi plecami”. Jest to a fortiori prawdą również wtedy, gdy w grę wchodzą stosunki bardziej złożone niż rodzinne $\mathrm{e}^{11}$.
\end{abstract}

Codzienne doświadczanie świata wypełnionego codziennymi, społecznie podzielanymi treściami prowadzi do stworzenia zestandaryzowanych wzorów zachowań. We wzorach tych, złożonych z czynności podejmowanych o określonych porach roku czy doby, zawarty jest sens samych działań, jak też odzwierciedla się społecznie ugruntowana wiedza o świecie. Umożliwia to podejmowanie czynności wobec konkretnej, zrozumiałej dla wszystkich uczestników świata sytuacji bez roztrząsania świata tego niuansów, jak też bez konieczności rozpatrywania sensu pojedynczego działania.

${ }^{10}$ Bliskość oznacza tu sfery życia, z którymi człowiek ma często do czynienia. Może ona oznaczać zarówno świat swój - ograniczony do własnej lokalności, jak też sferę życia najbardziej istotną ze względu na jego miejsce w świecie (wykonywany zawód, status społeczny itp.) i podejmowane w związku z nim działania.

${ }^{11}$ P. L. Berger, T. Luckmann, Społeczne tworzenie rzeczywistości, tłum. J. Niżnik, Państwowy Instytut Wydawniczy, Warszawa 1983, s. 82. 
Wychodziło się koło dwudziestego lipca, (...) z całym dobytkiem się tam mieszkało. To takie koczownicze życie. (...) My tam w górach mieli tak, jak w tym osiedlu - było 6 bud na około. Koczowali my tam jak Cyganie dawniej.

(...) I tak dwa tygodnie. 22 lipca śli na grodzenia. Tam się wynosiło ze wszystkim, kosiło trawę na siano. Mieli my tam polany, łąki my mieli i mieszkało się tam.

(...) Wieczorem siedzieli my, śpiewali, wódkę się piło przy ognisku. Wtedy to nie było tej kiełbasy, to słoninę na patyki... Różnie to to było, ale wesoło. Każdy polanę miał to ludzi było więcej jak tu, $\mathrm{w}$ dole. Ku pannom się chodziło...12

Wspólna kośba ${ }^{13}$, którą wspomina jeden z ochotnickich gazdów, była przykładem wykształconego wzorca zachowań zawierającego w sobie działania posiadające pozornie odmienny sens. Czasowe mieszkanie poza wsią, koszenie trawy, biesiadowanie czy chodzenie „ku pannom” rozpatrywane osobno odnoszą się do różnych aspektów racjonalności, związane są z odmiennymi względem siebie sensami pracy i rozrywki. Odniesienie ich do sensu kośby, rozumianej przez wszystkich jej uczestników jako cyklicznie powtarzający się integralny zespół zachowań, miejsca i czasu powoduje uprawomocnienie wpisania czynności zabawy w zestandaryzowany wzór wspólnej pracy.

Tradycyjne formy gospodarowania, związane z wzajemną pomocą, czy działania podejmowane wspólnie „z konieczności”, wywołujące szczególne poczucie wspólnotowego „my” wyrażonego w stwierdzeniach: „siedzieli my, śpiewali”, „mieli my” lub w pozornie bezosobowych formach „chodziło się”, „piło się”, odnoszą się do zasobów wiedzy społecznie dystrybuowanych i społecznie podzielanych w granicach tradycyjnego świata lokalnego. Mówiąc inaczej, były działaniami mającymi na celu zabezpieczenie podstawowych potrzeb poszczególnych ludzi i lokalnej społeczności, które w obrębie ich świata były działaniami jedynymi znanymi lub jedynymi będącymi w zasięgu. Ich interpretacja, prowadząca do uznania ich za racjonalne, nie wymagała wykroczenia poza granice świata tradycyjnego, w którym lokowali oni swe działania. Zaznaczyć przy tym należy, że

„racjonalne działanie” w życiu codziennym jest zawsze działaniem wewnątrz nieokreślonego, nie kwestionowanego układu konstruktów, odnoszących się do typowych sytuacji, motywów, celów, przebiegów działań, osobowości traktowanych jako „oczywistość”. Są one bezdyskusyjne nie tylko dla aktora, ale przypuszcza się,

12 Materiały z badań w Ochotnicy, AEiAK 12161.

${ }^{13}$ Tak mieszkańcy Ochotnicy określają koszenie łąk. Kośba oparta na zasadach pomocy wzajemnej funkcjonuje jeszcze w szczątkowej postaci wśród właścicieli łąk położonych na południowym ramieniu Gorca. 
że są takimi także dla jego bliźniego. (...) Im bardziej zestandaryzowany jest wzór działania, im bardziej jest on anonimowy, tym większa subiektywna szansa dostosowania się, a więc sukcesu intersubiektywnego zachowania. A jednak - i to jest paradoks racjonalności na poziomie potocznego myślenia - im bardziej zestandaryzowany jest wzór, w tym mniejszym stopniu jego zasadnicze elementy dają się racjonalnie analizować $\mathrm{w}$ potocznym myśleniu ${ }^{14}$.

Taka standaryzacja działań umożliwiała uczestnikom świata tradycyjnej wsi odnosić sens pojedynczych czynności do czytelnego i powtarzalnego wzoru. Skoro działanie wobec powtarzalnych sytuacji, takich jak praca na roli, uczestnictwo w nabożeństwie czy wspólne śpiewanie, opierało się na działaniach podejmowanych w myśl zasady „tak czynią wszyscy”, działanie to musiało mieć sens. Inaczej nieracjonalne stałyby się nie tylko pojedyncze czynności czy wzory zachowań, ale cała rzeczywistość, wobec której i w której były one realizowane. Rzeczywistość stanowiąca świat życia codziennego mieszkańców tradycyjnej wsi, rzeczywistość konstruowana "tu i teraz”, będąca także odrębną względem innych, podobnych ograniczoną dziedziną znaczenia - rzeczywistością pozostającą w zasięgu i rządzącą się własnym porządkiem poznawczym ${ }^{15}$.

Przytoczone we wstępie szykowanie pługów do pierwszej orki wydaje się nieracjonalne jeśli spróbujemy je uprawomocnić przez pryzmat porządku poznawczego i logicznego globalizującego się świata. Jednak jeśli stanowi ono element zestandaryzowanego wzoru działania odniesionego do sensu tradycyjnego świata, staje się oczywistym, że gazda musi naszykować narzędzia by zaorać pole; a także, że musi zaorać pole, ponieważ jest gazdą. Ponadto dlatego, że tak robią inni gazdowie, stale rekonstruując tradycyjny świat „dany od Boga”, opierający się na czytelnym układzie znaczeń stanowiącym uświęcony tradycją ład, będący stałym doświadczaniem sensów podzielanych przez wszystkich jego mieszkańców.

We współczesnej wsi, także we współczesnej Ochotnicy, nie wszyscy jej mieszkańcy odnoszą swe działania do tradycyjnych treści i do lokalnie ukonstytuowanych wzorów działania. Nie sposób nie zauważyć postępującej homogenizacji kultury wsi z kulturą globalizującego się świata, odejścia od tradycyjnych form zarobkowania czy „ludowych” stylów życia. Jednak poszukiwanie własnej swoistości, odwoływanie się do przeszłości czy tradycji

${ }^{14}$ A. Schütz, Potoczna i naukowa interpretacja..., s. 175-176.

${ }_{15}$ Zob. A. Schütz, O wielości światów... 
mogących tę swoistość podkreślić czy wręcz uprawomocnić widoczne jest w wielu działaniach mających na celu określenie sensu swojego miejsca w świecie jako świata lokalnego.

\section{Kultura ludowa a lokalność}

Kultura ludowa we wszelkich opracowaniach z dziedziny nauk społecznych, a także w języku potocznym, przypisana jest zbiorowościom wiejskim. „Lud”, oznaczać miał wsi tej rdzennych mieszkańców, będących chłopami lub po przekształceniu się społeczeństwa stanowego $\mathrm{w}$ społeczeństwo nowoczesne, z chłopstwa się wywodzących. Mimo obecności na wsi przedstawicieli innych stanów (później warstw czy klas społecznych), to członkowie tak rozumianego ludu mieli być kultury tej uczestnikami, twórcami i nośnikami, biorącymi udział w transmisji treści opartej na bezpośrednim przekazie, nie wykorzystującym słowa pisanego. Z takiego rozumienia ludu, oraz z tak interpretowaną transmisją, utożsamianą najczęściej z przekazem tradycji, wykształciły się terminy mające zastępować termin „kultura ludowa” i wskazujące inne niż samo pochodzenie jej uczestników cechy - jak chociażby „kultura tradycyjna” czy „kultura tradycyjnej wsi”. Niezależnie od terminu, kultura ta zawsze rozpatrywana była jako zespół treści przynależnych rdzennym mieszkańcom wsi i przekazywanych poprzez samo w tej kulturze uczestnictwo. Bezpośredni przekaz międzypokoleniowy i przestrzenny (np. zapożyczenia z kultur sąsiednich), jak też wiele podobnych czy wręcz identycznych treści można by było odszukać w kulturze ludności miejskiej przed rewolucją przemysłową (w małych miasteczkach także długo po niej), która żyła według podobnych norm i wyznawała podobne wartości, jak też w kulturze napływających do nowych ośrodków przemysłowych robotników, przenoszących ze sobą jedyne znane im treści z rodzinnych wsi. Mimo to, dla określenia zespołu treści występującego wśród robotników wykształcił się termin „kultura robotnicza”, zaś kulturę dawnych miast włączono w zunifikowaną kulturę europejską danej epoki kultura średniowiecza, renesansu czy oświecenia.

Myśl strukturalna wykształciła model kultury ludowej rozumianej jako pewien typ kultury, przeciwstawiany modelowi „kultury wysokiej”, a także modelowi kultury masowej. Model kultury ludowej, z determinantami opisanymi przez Ludwika Stommę (izolacja - pozioma, pionowa i świado- 
mościowa, rytualizm, sensualizm, moralność i ustny przekaz tradycji ${ }^{16}$, zasadzał się na binarnych układach znaczeń prowadzących do wartościowania ich w najważniejszej zdaniem strukturalistów dychotomii swój - obcy. W „kulturze typu ludowego” mieściłby się także model kultury dawnych miast, czy model kultury robotniczej, dzięki odróżnieniu jej od zunifikowanej kultury masowej poniższym zestawieniem znaczeń:

kultura ludowa
regionalna
spontaniczna
bezpośredni ustny przekaz
nastawiona na uczestnictwo
wspólnotowa
systemowa, wieloznacząca
wiejska
adresowana do określonego odbiorcy
mało zmienna, wolny przepływ
informacji

kultura masowa
powszechna
skomercjalizowana
mechaniczne środki przekazu
zabawowa, bierna
rodząca samotność
zhomogenizowana $_{\text {miejska }^{17}}$
nastawiona na średniego odbiorcę $_{\text {szybko zmienna, duża ilość }}$
informacji ${ }^{18}$

Takie pojęcie kultury ludowej ukształtowane w myśli naukowej przeniknęło do społecznie podzielanych zasobów wiedzy, w których uległo wspomnianej już mityzacji polegającej na urzeczywistnieniu oderwanych od „ludowego” czy „tradycyjnego” kontekstu znaczeń w formie najróżniejszych rekonstrukcji „dawnego świata” ${ }^{\prime 19}$. Treści kultury ludowej dostępne w ofercie muzeów etnograficznych, skansenów czy izb regionalnych, a także wiejskich festynów, warsztatów rzemiosła czy straganów ze „sztuką ludową”, stały się upowszechnione, zabawowe, skomercjalizowane i adresowane do „średniego odbiorcy” - jednym słowem „umasowione”. Kolejną mityzacją była obiektyzacja kultury ludowej jako „pierwocin” polskiej kultury narodowej. Doprowadziło to do unifikacji ludowych treści, które przestały być wyznacznikami regionalnej czy lokalnej specyfiki a stały się ogólnie dostępnym i instytucjonalnie dystrybuowanym dobrem. Uczniowie zarówno wiejskich, jak i miejskich szkół, niezależnie od regionu, w którym mieszkają,

${ }^{16}$ L. Stomma, Determinanty polskiej kultury ludowej XIX wieku, „Polska Sztuka Ludowa” 1979, nr 3, s. 131-143.

${ }^{17}$ Jest to w zasadzie jedyna dychotomia lokująca kulturę ludową poza miastem.

${ }_{18}$ Cz. Robotycki, Myślenie typu ludowego w polskiej kulturze masowej (propozycje badawcze), „Etnografia Polska” 1985, z. 1, s. 112-113.

${ }^{19}$ Zdaję sobie sprawę, że mityzacja ta dotyczyła także (i wcześniej niż stało się to w myśleniu potocznym) myślenia naukowego (zob. Cz. Robotycki, S. Węglarz, Chłop potęgq jest...). 
uczą się „ogólnie ludowych” (a więc polskich) krakowiaków, trojaków, polek, podobnie jak Zespół Pieśni i Tańca Mazowsze ma w swoim repertuarze stylizacje folklorystyczne z terenu całego kraju. Treści kultury ludowej oderwane od kontekstu, w którym powstały, stały się zatrzymanym w czasie, zarchiwizowanym i spisanym (!) tekstem dostępnym w każdym czasie i miejscu, gotowym do rekonstrukcji na dowolnym poziomie dokładności (np. „wiejskie” oczepiny podczas miejskiego wesela lub góralska karczma na Kujawach).

Pora jednak wrócić nie tylko do mityzacji kultury ludowej jak też samej ludowości, ale do rozumienia kultury wskazanego przez J. S. Bystronia, dla którego stanowi ona zespół treści wykształconych w konkretnej grupie i w konkretnym czasie. To dookreślenie pojęcia kieruje namysł badawczy na związek kultury ludowej z lokalnością - bytem zakorzenionym w świecie życia codziennego ludzi realizujących swe działania „tu i teraz”.

W przywoływanej przeze mnie już kilkukrotnie w tym tekście Ochotnicy pojawiły się działania odniesione do „tradycyjnego” ładu, do kultury rozumianej po Bystroniowsku, jako zespół treści - nie ogólnie „ludowej” czy „typu ludowego” ale własnej, lokalnej, ochotnickiej. Prócz wspomnianego szykowania narzędzi do orki i wspólnej kośby doszło tu do rekonstrukcji miejscowego stroju, przywrócenia chowu owiec i gospodarki szałaśniczej, także do prób odtworzenia ochotnickiego folkloru. Działania te, rozpoczęte inicjatywą miejscowych „pasjonatów” spotkały się z akceptacją znacznej części mieszkańców tej gorczańskiej wsi - na tyle, że w Wiejskim Ośrodku Kultury w Ochotnicy Górnej działa zespół folklorystyczny „Ochotni”, kilka osób podjęło się szycia i haftowania stroju, a na zarastające gorczańskie polany powracają cakle - rodzima rasa owiec odpornych na surowy klimat i dość jałową miejscową trawę porastającą miejscowe hale i polany. Można doszukiwać się tutaj prób zwiększenia atrakcyjności turystycznej Ochotnicy $^{20}$ - podejmowane w tym celu działania możemy przecież obserwować w różnych miejscowościach i regionach Polski. Jednak tutaj (w Ochotnicy) działania te są dla ich autorów istotnym składnikiem lokalnej identyfikacji, próbą uprawomocnienia tradycyjnych treści w rzeczywistości globalizującego się świata:

${ }^{20} 0$ tym aspekcie rekonstrukcji kultury tradycyjnej piszę $\mathrm{w}$ innej publikacji. Zob. P. Schmidt, Tradycje i jej (re)konstrukcje a atrakcyjność turystyczna świata lokalnego. Przykład Ochotnicy, [w:] Kultura i rynek. Interdyscyplinarne szkice humanistyczne, pod red. E. A. Jagiełło i P. Schmidta, E-naukowiec, Lublin 2013, s. 29-60. 
Byłeś u mego stryjka, Ludwika - béł ostatnim uochotnickim bacą. Ktoz teraz ma te tradycje podtrzymać? Jo mam hale, mom gazdówke na Jaszczach i co? Mam rzucić? Nié! Kupiłek uowce i co by se mi zona rzekła - opłaca sie abo nié, idem z śniemi na Ślagową i pasem. Tak jak z muzykowaniem. (...) Jesce kiej byłek takim srojtkiem małym, w kozdyj chałpie béły uowce i była muzyka. Kozden jeden abo grał abo śpiywać potrafiéł. Ino nie tak, jak w Zakopanem, pod publicke. Tu béło prawdziwe góralskie śpiywanie, prawdziwa góralska muzyko. Przyiseł chłop jeden, drugi, cosik se ugodali, wypili i juz nuta sie rozchodziéła. I my tej nuty ucymy, co by młodziez starej uochotnickiej tradycji nie zabacyła ${ }^{21}$.

Odniesienia do przeszłości, odniesienia do tradycji mogą świadczyć o potrzebie przywoływania przeszłości, przywoływania tradycyjnych treści w celu uprawomocniania działań znanych z dzieciństwa lub z przekazów rodziców i realizowanych współcześnie. Odnoszenie współcześnie podejmowanych działań do kultury tradycyjnej jawi się jako próba opanowania chaosu nowoczesności przez wartości i normy przynależne do przednowoczesnego świata. Kultura - niekoniecznie tradycyjna - porządkuje bowiem, jako konstrukt społecznie podzielanej wiedzy, płynne, niedookreślone lub zmieniające sens znaczenia, odwołując nas do społecznie ukonstytuowanego i ugruntowanego siłą tradycji zespołu norm, wartości, nakazów i zakazów charakterystycznych dla teleologicznego, zrozumiałego ładu. 0 kulturze, mimo zmieniającej się „na naszych oczach” rzeczywistości myślimy, jak zauważy Z. Bauman, jako o

wysiłku zaprowadzenia i utrzymania ładu. Jako o wojnie z żywiołowością i tym
chaosem, co się z żywiołowości poczyna. W wojnie ładu z żywiołem kultura staje
bez wahania po stronie ładu. Gdy postrzegamy niespójność norm, wieloznaczność
postępowania, sprzeczności w stylach życia, obfitość tworów kulturowych w sposób
widoczny „bez przydziału” - powiadamy albo o konflikcie wielu kultur, albo o kryzysie
kultury.W jednym i drugim przypadku oczekujemy przykrego obrotu rzeczy i skłonni
jesteśmy wołać na alarm...22

Rekonstrukcja tradycyjnych treści (powrót stroju i folkloru) lub ich krzewienie (kontynuowanie tradycyjnego gospodarowania) są próbą przeciwdziałania chaosowi globalizującego się świata. Są poszukiwaniem ładu w lokalnych treściach znanych z dzieciństwa lub z przekazów rodziców, treściach odwzorowujących wyidealizowany świat tradycyjnej, góralskiej wsi przeciwstawiany ponowoczesnej, płynnej rzeczywistości. Taka indy-

${ }^{21}$ Dziennik terenowy z badań w Ochotnicy, $2010 \mathrm{r}$.

22 Z. Bauman, Ponowoczesność jako źródło cierpień, Wydawnictwo Sic!, Warszawa 2000, s. 186. 
genizacja treści i działań wymaga od podejmujących je ludzi wykroczenia poza ramy doświadczanego na co dzień Lebenswelt i ograniczenia konstruowanej w ten sposób rzeczywistości do znaczeń rdzennych, wyrosłych w lokalnej kulturze. Każde takie wykroczenie poza ramy codziennego świata jest zdaniem A. Schütza związane z szokiem wywołanym gwałtownym przejściem w sferę odmiennych znaczeń, innych układów racjonalności, innych porządków poznawczych ${ }^{23}$. Przykładem takiego przekraczania światów może być granie góralskiej muzyki. Występ ochotnickiej kapeli w pensjonacie czy podczas zorganizowanego dla turystów kuligu odnosi się do nowoczesnego świata - jest po prostu teatralną rekonstrukcją miejscowego folkloru, atrakcją dla przybyszów i okazją do zarobku dla miejscowych muzykantów. To samo działanie przeniesione w sferę lokalności - bądź w postaci wspólnego muzykowania „dla samych siebie”, bądź podczas zajęć z młodzieżą - wymaga podjęcia roli reprezentanta własnej kultury, odniesienia sensu działania do lokalnego świata konstruowanego zespołem tradycyjnych treści.

Ochotnicka lokalność jest dla jej uczestników nierozerwalnie związana z kulturą tradycyjną. Możliwe, że związek ten wynika z podzielanej społecznie pamięci tradycyjnego świata, który trwał tu jeszcze niespełna 50 lat temu, aż do chwili zelektryfikowania wsi, co przeniosło Ochotnicę w epokę i świat nowoczesności. Niemal powszechna znajomość treści „dawnego świata” pozwala jego mieszkańcom lokować swoje działania w kontekście kultury tradycyjnej, akceptować wzory działania wykraczające poza świat płynnej nowoczesności.

\section{Po co badać kulturę ludową?}

Zdaję sobie sprawę, że nie każdy świat lokalny konstruowany jest w odniesieniu do kultury tradycyjnej czy choćby do wyniesionych z niej treści. Oczywistym jest także, że współczesna ochotnicka lokalność jest raczej intencjonalną rekonstrukcją tradycyjnego świata tej wsi niż jego urzeczywistnieniem. Rekonstrukcja ta nie zawsze musi być związana z teatralizacją działań. Potrzeba porządkowania chaosu ponowoczesności kieruje mieszkańców lokalnych światów ku tradycyjnym treściom, które w przypadku Ochotnicy są o tyle aktualne, o ile pozostały zapamiętane i wykorzystywane w codziennych sytuacjach. Tak funkcjonujące treści tradycyj-

\footnotetext{
${ }^{23}$ Zob. A. Schütz, O wielości światów...
} 
nej kultury prowadzą do wytworzenia swoistej wspólnoty konstytuowanej wokół doświadczania lokalności. Wspólnoty, która porządkuje świat i która może nadal przesądzać o jego istocie. Zdaniem Izabelli Bukraby-Rylskiej

\begin{abstract}
...zjawisko wspólnoty lokalnej-jako jed ności miejsca, grupy, sieci interakcji i wzorów kultury - ów idealny konstrukt, (...) odzyskuje swoją konkretność i pełnię. Ponowne zbieganie się czynników, kiedyś przesądzających o istocie zjawiska, a następnie podległych procesom rozpadu i dekompozycji, okazuje się zatem w pewnych warunkach możliwe także obecnie, choć oczywiście powstałe dziś formy nie mogą być traktowane jako identyczne pod każdym względem z wcześniejszymi ${ }^{24}$.
\end{abstract}

Zdaję sobie sprawę, że nie w każdym świecie lokalnym możliwe jest ukonstytuowanie się tego „idealnego konstruktu”. Ponadto myślenie o kulturze ludowej, a także o kulturze w ogóle, jako o czynniku porządkującym chaos ponowoczesnego świata nie jest wolne od idealizacji - dokonywanej zarówno na poziomie teoretycznych analiz, jak i w myśleniu potocznym. W świecie relatywnych znaczeń, zamieszkałym przez, używając Baumanowskiej metafory, „,mgławicowe wspólnoty”, pojęcia kultury, tradycji czy ładu przestają być jednoznacznie wartościowane. Skoro zawierają się w nich znaczenia, które zanim świat wkroczył w erę płynnej nowoczesności pojmowane były pejoratywnie, obecnie zaś zależą od subiektywnych osądów, pojęcia te stają się coraz mniej zasadne w próbach porządkowania chaotycznej, zrelatywizowanej rzeczywistości.

Coraz trudniej dziś myśleć w ten sposób i mówić o kulturze: kryzys stałby się wszak wtedy codziennością, nienormalność normą, choroba stanem chronicznym. (...) Zaczy namy podejrzewać, że coś jest z tymi pojęciami nie w porządku; że nie tyle objaśniają one, co się dzieje, ile zrozumieć świat przeszkadzają; że są balastem raczej, niż motorem poznania i rozumienia; że się z tym balastem daleko nie zajdzie... Innymi słowy nadszedł czas odrzucenia starego paradygmatu i dopracowania się nowego, który pozwoli dostrzec „normalność” tego, co dawny paradygmat ogłosił anomalią i odstępstwem od reguły - tak aby wyjątki stały się znów marginalne a zjawiska marginalne wyjątkami... ${ }^{25}$

Słowa Z. Baumana traktują o świecie poddanym ciągłemu procesowi niekontrolowanych zmian zwanych globalizacją. Kultura w globalizującym się świecie, podobnie jak tradycja i inne pojęcia „porządkujące”, stała się

${ }^{24}$ I. Bukraba-Rylska, Socjologia wsi polskiej, Wydawnictwo Naukowe PWN, Warszawa 2008, s. 54.

25 Z. Bauman, Ponowoczesność..., s. 186-187. 
znaczeniem odnoszonym do wielu niezwiązanych ze sobą kontekstów, pojęciem zawierającym znaczenia z wielu odrębnych rzeczywistości. Nikogo już chyba nie dziwią hybrydowe zjawiska w postaci „pizzy góralskiej”, Polskiej Unii Buddyjskiej czy wszechobecnych w języku mediów „briefingów”. Kreolizacja kultury prowadzi do swobodnego sięgania po znaczenia z innych światów, do konstytuowania sensów obcych lokalnej rzeczywistości a jednak tę rzeczywistość na nowo konstytuujących. W społecznie podzielanych zasobach wiedzy mieszkańców ponowoczesnego świata kultura ludowa stała się mitem opisującym mityczny świat - rzeczywistość dawnego, niepamiętanego jużładu, spokoju i sielskości, możliwych do doświadczenia tylko podczas wyrwanych z przynależnego im kontekstu teatralnych rekonstrukcji.

Myślenie o kulturze ludowej jako o zasobach treści służących rozumieniu świata tradycyjnego, nie jak o micie może jednak służyć zrozumieniu nie tylko dawnego ale także współczesnego zjawiska lokalności. Przy założeniu, że treści kultury opisują Lebenswelt każdego człowieka, że stanowią dla niego podstawową i będącą w zasięgu ramę znaczeń konstytuujących jego świat, ważnym staje się dla badacza poznanie sensów, do których badani odnoszą swe działania podejmowane zawsze w biograficznie zdeterminowanej sytuacji. Gdy działania nakierowane są na ich lokalność, gdy w konstruowaniu własnego świata istotna staje się sfera lokalności jej uczestnicy sięgają po treści tradycyjne, „ludowe”, wyodrębniające świat lokalny z ogółu rzeczywistości.

Jakkolwiek rozumiana kultura ludowa jest bytem odnoszącym się do przeszłości i z przeszłości wydobywanym poprzez okazjonalne rekonstrukcje dokonywane przez uczestników nowoczesnej, masowej kultury. Współczesny badacz może badać ją jako historyczną zaszłość (choć wydaje się, że tak sformułowany problem został już wyczerpany) lub badać fenomen jej rekonstrukcji w (po)nowoczesnej rzeczywistości społeczno-kulturowej.

Współczesne badanie kultury lokalnej, czy świata lokalnego polegałoby zatem na badaniu różnych sfer życia codziennego i wyłonieniu, które ze znaczeń badani odnoszą do nowoczesnej, wykraczającej poza lokalność rzeczywistości, które zaś traktują jako tradycyjne, rdzenne, lokalne. Współistnienie w odrębnych światach jest zdaniem A. Schütza niemożliwe - człowiek przekraczający granice światów doznaje swego rodzaju szoku związanego z przeskokiem z jednej ograniczonej dziedziny znaczeń do drugiej, jak ma to miejsce choćby przy powrocie ze świata fantazji do świata życia 
codziennego ${ }^{26}$. Światy te są bowiem zespołami na tyle różnych znaczeń, że interpretacje podobnych nawet doświadczeń z dwóch różnych dziedzin znaczenia są ze sobą niezestawialne. Założenie to wydaje się zasadne dla tworzenia opisu świata tradycyjnego, w którym mieszkaniec tradycyjnej wsi podejmując działanie w zewnętrznej dla tego świata rzeczywistości (np. podejmując pracę sezonową w „obcych stronach”) odnosił je do sytuacji kreowanej w tym właśnie zewnętrznym świecie. Po powrocie, dzieląc się wspomnieniami z mieszkańcami swojego świata kreował wizję exterioru $\mathrm{w}$ odniesieniu do znaczeń odnoszonych do znanego, swojego świata lokalnego.

W epoce ponowoczesności, tworzącej chaotyczne lub przynajmniej nieczytelne zespoły sensów, wydaje się, że transcendencja poza określoną dziedzinę znaczenia nie wymaga całkowitego zerwania z odnoszonymi do niej sensami. Mówiąc inaczej, w płynnej nowoczesności znaczenia niemal swobodnie przenikają pomiędzy różnymi światami i są (często bezrefleksyjnie) przypisywane treściom z innego porządku sensów. Dlatego mogę uczestniczyć w miejskim weselu z wiejskimi oczepinami, kreując z innymi biesiadnikami niejako hybrydową, lokalno-masową sytuację, odnoszoną jednocześnie do dwóch, wydawałoby się rozdzielnych, dziedzin znaczenia.

Podobnie hybrydowymi sytuacjami są rekonstrukcje tradycyjnego świata w ramach „ludowych” festynów, konkursów czy przeglądów łączących ze sobą dawny folklor czy zwyczaje będące sensami kreującymi tradycyjny świat z ponowoczesnymi, konsumpcyjnymi atrakcjami dla szerokiej rzeszy odbiorców. Takie teatralizacje dawnego świata (występ zespołu folklorystycznego na scenie czy kulturowy wypas owiec w pełnych strojach) podejmowane są najczęściej przez instytucje (ośrodki kultury, lokalne grupy działania, stowarzyszenia agroturystyczne) mające na celu udostępnienie odbiorcom z zewnątrz pojedynczych treści, najczęściej wyrwanych z kontekstu ogółu lokalnego świata, oraz potencjalny zysk związany z poszerzeniem asortymentu atrakcji turystycznych czy turystycznej atrakcyjności regionu. W takim przypadku treści świata lokalnego przeniesione zostają do nielokalnej dziedziny znaczenia.

W lokalnym świecie, będącym dla jego mieszkańców światem życia codziennego, podejmowane są jednak inne, nieinstytucjonalne działania, w których można znaleźć rekonstrukcje świata tradycyjnego i które

${ }^{26}$ Zob. A. Schütz, O wielości światów... 
są podejmowane wobec codziennych, lokalnie kreowanych sytuacji. To na przykład mówienie gwarą, centralne lokowanie swojego miejsca w myśleniu o świecie, antagonistyczne sądy o sąsiedniej społeczności odzwierciedlające dychotomię swój - obcy, wyrób sera na własny użytek lub na potrzeby sąsiedzkiej wymiany za inny produkt żywnościowy ${ }^{27}$, czy wreszcie założenie stroju w niedzielę. Takie działania podejmowane „tu i teraz” wobec codziennych sytuacji odnoszą się do świata lokalnego oraz do kreowanej wspólnie z innymi mieszkańcami tego świata, intersubiektywnie przez nich doświadczanej i interpretowanej lokalności.

Działania te nie odtwarzają oczywiście całego zasobu znaczeń tradycyjnej kultury - nie ma obecnie warunków ani potrzeby, by współcześnie stworzyć „na nowo” świat odizolowany przestrzennie i świadomościowo, oparty na systemie wartości odnoszącym się do nieaktualnej już wizji teleologicznego ładu kojarzonego z boskim porządkiem. Działania te, podejmowane zawsze wobec konkretnej, często spontanicznie wywołanej sytuacji odnoszone są nie do całościowego kontekstu tradycyjnego zespołu znaczeń, ale do kontekstu sytuacyjnego właśnie. To, że niosą treści tradycyjnej kultury nie oznacza, że należy traktować je bardziej jako artefakty dawnego ładu niż współczesne kreacje codzienności. Może tu właśnie jest zadanie dla etnologa?

W większości światów lokalnych, w których prowadziłem badania, dało się odczuć ambiwalentny stosunek ich mieszkańców do własnych tradycji. Z jednej strony strój czy gwara (nawet jeśli istniały jedynie w pamięci rozmówców) stanowiły obiekt identyfikacji z lokalnym światem i zakładaną w wywołanej wywiadem refleksji wspólnotą terytorialną, z drugiej były znaczeniami kojarzonymi z „wstydliwą” wiejskością, negatywnie wartościowanym konserwatyzmem czy zacofaniem. Może poparte badaniami konkretnej lokalności animowanie i popularyzacja tradycyjnych wzorców zachowań spowodowałoby pozytywne wartościowanie tradycyjnych treści, które mogłyby stanowić o odrębności konkretnego świata lokalnego, które byłyby odniesieniami lokalnej identyfikacji, wreszcie stałyby się równoprawnymi dla instytucjonalnie podejmowanych inicjatyw kreacją (niekoniecznie rekonstrukcją) lokalności mogącą zaspokajać potrzebę „bycia

27 Z taką sytuacją spotkałem się m.in. w Czarnej Górze na Spiszu niespełna dwa lata temu. Gaździna, u której nocowałem codziennie wymieniała własnej roboty twaróg na jajka kur chowanych przez sąsiadkę. 
sobą" uczestników lokalnego świata i jednocześnie potrzebę doświadczania „autentycznej wsi” dla będących konsumentami lokalnej oferty turystów.

W powyższym aspekcie, kultura ludowa - ze świadomością lokalnych odrębności i zdezaktualizowania treści, które świadczyły o jej istocie (wspólnotowość, bezpośredni przekaz treści, szeroko rozumiana izolacja) może stać się perspektywą badań i opisu świata lokalnego. Nie widzę jednak potrzeby dalszego wnikania w jej istotę, jako sensu uniwersalnego czy typu nakładanego poprzez naukowe lub potoczne generalizacje na odmienne i odrębne światy lokalne. Badanie „dawnego” świata tradycyjnego należałoby ograniczyć do konkretnej lokalności. Jeśli lokalność, rozumiana jako zespół treści konstytuujących dany świat, odnosi się do tradycji, badaczowi niezbędna jest wiedza o kulturze ludowej by lokalność tę - stanowiącą ograniczoną dziedzinę znaczenia - zrozumieć. Jest tu miejsce dla badań etnograficznych połączonych z działaniem wśród liderów społeczności próbujących rekonstruować wybrane treści tradycyjnej kultury. Działacze lokalnych grup działania, ośrodków kultury czy nawet właściciele lokali gastronomicznych i gospodarstw agroturystycznych podejmują się rekonstrukcji dawnego świata, które często przypominają działania grup rekonstrukcyjnych i tak są postrzegane przez mieszkańców lokalnego świata. Badania etnograficzne połączone z współdziałaniem z lokalnymi liderami mogą prowadzić do wypracowania i upowszechnienia zestandaryzowanych wzorów zachowań przywracających tradycyjne działania jako działania podejmowane wobec własnej lokalności w realiach nowoczesnego świata.

\section{BIBLIOGRAFIA}

- Bauman Z., Ponowoczesność jako źródło cierpień, Wydawnictwo Sic!, Warszawa 2000.

- Bauman Z., Wieloznaczność nowoczesna - nowoczesność wieloznaczna, Wydawnictwo Naukowe PWN, Warszawa 1995.

- Berger P. L., Luckmann T., Społeczne tworzenie rzeczywistości, tłum. J. Niżnik, Państwowy Instytut Wydawniczy, Warszawa 1983.

- Bukraba-Rylska I., Socjologia wsi polskiej, Wydawnictwo Naukowe PWN, Warszawa 2008.

- Bystroń J. S., Kultura ludowa, Wydawnictwo Trzaska, Evert i Michalski, Warszawa 1947.

- Robotycki Cz., Myślenie typu ludowego w polskiej kulturze masowej (propozycje badawcze), „Etnografia Polska” 1985, z. 1. 
- Robotycki Cz., Węglarz S., Chłop potęga jest i basta. O mityzacji kultury ludowej w nauce, „Polska Sztuka Ludowa” 1983, nr 1-2.

- Schmidt P., Tradycje i jej (re)konstrukcje a atrakcyjność turystyczna świata lokalnego. Przykład Ochotnicy, [w:] Kultura i rynek. Interdyscyplinarne szkice humanistyczne, pod red. E. A. Jagiełło i P. Schmidta, E-naukowiec, Lublin 2013.

- Schütz A., O wielości światów. Szkice z socjologii fenomenologicznej, tłum. B. Jabłońska, Zakład Wydawniczy »NOMOS«, Kraków 2008.

- Schütz A., Potoczna i naukowa interpretacja ludzkiego działania, [w:] Kryzys i schizma. Antyscjentystyczne tendencje w socjologii współczesnej, t. 1, pod red. E. Mokrzyckiego, Wydawnictwo Naukowe PWN, Warszawa 1984.

- Stomma L., Determinanty polskiej kultury ludowej XIX wieku, „Polska Sztuka Ludowa” 1979, nr 3.

- Sulima R., Kultura ludowa i polskie kompleksy, [w:] Czy zmierzch kultury ludowej?, pod red. S. Zagórskiego, Wydawnictwo Stopka, Łomża 1997.

- Wieruszewska M., Antropologizacja badań wsi. Zaniechania, potrzeby, możliwości, [w:] Nowe inspiracje socjologii wsi, pod red. H. Podedwornej, Wydawnictwo Naukowe SCHOLAR, Warszawa 2011.

THE CULTURE CALLED FOLK-CULTURE.

A DEFUNCT NOTION OR A PERSPECTIVE OF RESEARCH ON LOCALNESS?

The text is discussing contemporary meaning of the folk culture as the notion often appearing at Polish anthropological publications and in the colloquial language. Leaving from the problem of the mythologisation of the folk culture the author is seeking new meaning of this culture which can turn out to be useful in research of local world, the local communities or nature of the localness in postmodern woeld.

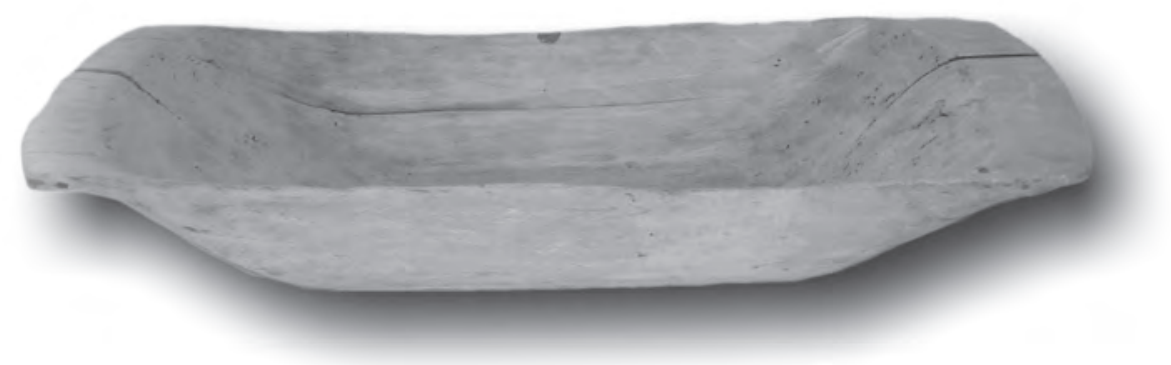

